\title{
Systematic review of studies investigating ventilator associated pneumonia diagnostics in intensive care
}

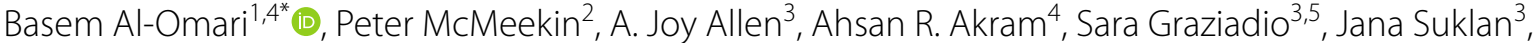 \\ William S. Jones ${ }^{3}$, B. Clare Lendrem³ ${ }^{3}$ Amanda Winter ${ }^{6}$, Milo Cullinan, Joanne Gray ${ }^{2}$, Kevin Dhaliwal ${ }^{4}$, \\ Timothy S. Walsh ${ }^{8}$ and Thomas H. Craven ${ }^{4,8}$
}

\begin{abstract}
Background: Ventilator-associated pneumonia (VAP) is an important diagnosis in critical care. VAP research is complicated by the lack of agreed diagnostic criteria and reference standard test criteria. Our aim was to review which reference standard tests are used to evaluate novel index tests for suspected VAP.

Methods: We conducted a comprehensive search using electronic databases and hand reference checks. The Cochrane Library, MEDLINE, CINHAL, EMBASE, and web of science were searched from 2008 until November 2018. All terms related to VAP diagnostics in the intensive treatment unit were used to conduct the search. We adopted a checklist from the critical appraisal skills programme checklist for diagnostic studies to assess the quality of the included studies.

Results: We identified 2441 records, of which 178 were selected for full-text review. Following methodological examination and quality assessment, 44 studies were included in narrative data synthesis. Thirty-two (72.7\%) studies utilised a sole microbiological reference standard; the remaining 12 studies utilised a composite reference standard, nine of which included a mandatory microbiological criterion. Histopathological criteria were optional in four studies but mandatory in none.
\end{abstract}

Conclusions: Nearly all reference standards for VAP used in diagnostic test research required some microbiological confirmation of infection, with BAL culture being the most common reference standard used.

Keywords: Ventilator-associated pneumonia, Diagnostics, Intensive care, Critical care

\section{Take home message}

1. This comprehensive systematic review assesses the reference standard tests used to evaluate novel index tests for suspected VAP in ICU over 10 years period
(2008 until 2018) and included high-quality studies with low risk of bias.

2. BAL culture is the most common reference standard used for VAP diagnostic in ICU and almost all reference standards required some microbiological confirmation of infection.

*Correspondence: basem.alomari@ku.ac.ae

${ }^{1}$ College of Medicine and Health Sciences, Khalifa University, PO

Box 127788, Abu Dhabi, UAE

Full list of author information is available at the end of the article

(c) The Author(s) 2021. Open Access This article is licensed under a Creative Commons Attribution 4.0 International License, which permits use, sharing, adaptation, distribution and reproduction in any medium or format, as long as you give appropriate credit to the original author(s) and the source, provide a link to the Creative Commons licence, and indicate if changes were made. The images or other third party material in this article are included in the article's Creative Commons licence, unless indicated otherwise in a credit line to the material. If material is not included in the article's Creative Commons licence and your intended use is not permitted by statutory regulation or exceeds the permitted use, you will need to obtain permission directly from the copyright holder. To view a copy of this licence, visit http://creativecommons.org/licenses/by/4.0/. The Creative Commons Public Domain Dedication waiver (http://creativeco mmons.org/publicdomain/zero/1.0/) applies to the data made available in this article, unless otherwise stated in a credit line to the data. 


\section{Background}

Ventilator-associated pneumonia (VAP) refers to inflammation of the lung parenchyma caused by infectious agents acquired specifically while receiving invasive mechanical ventilation $[1,2]$. VAP is a preventable nosocomial complication which potentially contributes to avoidable mortality and morbidity [3, 4]. Therefore, it is considered a clinically and epidemiologically important measure of the quality of care $[5,6]$. It contributes to additional resource consumption, adding time and expense to an intensive care stay, accounting for a large proportion of all antibiotic prescriptions [7]. VAP is considered to be responsible for an additional cost of approximately $\$ 40,000$ per episode in the US $[8,9]$ and around $£ 9000$ in the UK [10]. The contribution of an episode of VAP to mortality is difficult to definitively ascertain because of the high number and severity of confounders amongst the at-risk population [4, 11-13]. This attributable mortality has been reported from high to neutral or near-neutral [11-13].

Throughout recent decades investigators have not adopted a fixed set of criteria or a fixed definition for VAP [14]. This lack of a reference standard has led to an inability to make comparisons across study sets and uncertainty about VAP incidence [15]. The incidence of VAP varies widely in different studies depending on the diagnostic criteria used, type of intensive therapy unit (ITU), and patient population [16, 17].

Existing literature reports that the incidence of VAP varies widely between $4.0 \%$ and $28.8 \%$ of the at-risk population $[8,18-24]$, with an event rate between 1.4 and 16.5 per 1000 ventilator days [1, 25-27]. As VAP rates have become an important quality indicator, the Centre for Disease Control and the European Centre for Disease Control use their own precise case definitions to identify VAP events $[28,29]$. Both definitions return similar VAP rates making them adequate for surveillance purposes and benchmarking of critical care units internationally [1]. However, due to the lack of concordance between these two definitions, they do not make ideal reference standards [1,28], and further highlight the difficulty in achieving consensus in diagnosing VAP. Microbiological samples, especially quantitative culture of bronchoalveolar lavage (BAL), are considered to be integral to the diagnosis of VAP [30, 31]. However, a systematic review of diagnostic methods in 2008 found that microbiological methods did not contribute to the accuracy of diagnosis over clinical criteria and all respiratory sampling methods were equivalent [32]. The continuing lack of an agreed reference standard hampers research into novel diagnostic methods. The aim of this review was to identify what reference standards have been used in diagnostic evaluation research for VAP.

\section{Methods}

The protocol for this review was published in PROSPERO (International Prospective Register of Systematic Reviews) under registration CRD42019125449 [33].

\section{Search strategy}

A comprehensive search strategy was developed by one of the authors (BA). The Cochrane Library, PubMed (MEDLINE), CINHAL, EMBASE, and web of science were electronically searched from January 2008 until November 2018. We limited our search to studies published after 2008 following a comprehensive systematic review of diagnostic methods [32]. Medical Subject Headings $(\mathrm{MeSH})$ and search terms were used to interrogate the databases. The 3 concepts used for the searches were VAP, diagnostics, and ITU (for search terms see Additional file 1). No restriction on publication language was applied. In addition, electronic searching of Google and hand searching through an examination of the reference list of the published articles were also used to identify additional publications (an example of MEDLINE search is provided in Additional file 1).

\section{Review strategy}

All records were independently reviewed by the lead author (BA) and another author (PM or JG) and disagreement was resolved by a third independent adjudicator (PM or JG). Initially, titles and abstracts review of all records, then full-text reviews were conducted against the inclusion/exclusion criteria. Studies included in the review fulfilled the following criteria: (1) adult ventilated patients of any gender, (2) ITU settings, (3) suspected VAP as defined in this study (after $48 \mathrm{~h}$ on the ventilator), (4) focused on the diagnostic procedures of VAP (clinical markers, biomarkers, chest $\mathrm{x}$-ray, chest ultrasound (U/S), lung biopsy, BAL and mini-BAL, protected specimen brush (PSB), blind PSB, Endotracheal Aspirate (ETA)). Studies were excluded from the review if they: (1) were animal studies, (2) included patients under the age of 18 years old, (3) focused on the surveillance of VAP, (4) compared the diagnosis of VAP against another illness diagnostic, (5) were feasibility studies, (6) included participants who were already diagnosed with VAP, (7) investigated VAP treatment effectiveness by monitoring biomarkers or other diagnostics, (8) evaluated risk factors to predict VAP, (9) were procedures used to predict the mortality in VAP, (10) were case-controlled studies. All papers that passed the full-text review and those that had some diagnostic technical terms were examined by an 
ITU clinician (THC) to confirm their clinical relevance to the research question.

\section{Quality assessment and data extraction}

A team of 12 reviewers (systematic reviewers, clinicians, methodologists, health economists) from the University of Northumbria, Newcastle University, The Newcastle Upon Tyne Hospitals NHS Foundation Trust, and the University of Edinburgh were involved in the quality assessment and data extraction process. All included papers were quality assessed and the data were extracted by two authors independently. Any disagreement was discussed between both reviewers in the first instance. The further disagreement was resolved by a third reviewer. The quality assessment scoring checklist was adopted from the Critical Appraisal Skills Programme (CASP) checklist for diagnostic studies [34], which is one of the well-recognised methodological quality or risk of bias assessment tools for primary and secondary medical studies [35, 36] and has been used to assess the quality of diagnostic studies in systematic reviews [3739]. The quality assessment scoring checklist contains 8 questions from the overall 12 questions in the CASP checklist. Questions from section C in the CASP for diagnostics checklist "will the results help locally?" were not included in our scoring as the main aim of the review was not related to the local application of the diagnostic procedures. Studies were assigned a score of ' 1 ' for each item of the checklist if they were considered to meet the aspect of this item and ' 0 ' if not. A total score for each study was calculated by summing the item scores. The maximum possible final score was 8 . Any study that scored ' 0 ' for the first or the second question or scored less than ' 5 ' out of 8 in total was excluded. According to CASP guide for diagnostic studies, if the answer to question 1 or 2 while critically appraising a study was "no", then it is not worth continuing. That leaves 6 questions out of the total 8 we used in our quality assessment. Taking in consideration that these questions are equally as important but less important than the first 2 question, we determined that a study must fulfil the quality of at least half of these 6 points (score 3 out of 6 ) to be consider for the review. Therefore, this threshold was derived through reviewer consensus that studies scoring less than 5 out of 8 were not of sufficient quality to adequately address the research question.

A standardised data extraction form was developed by three authors (AJA, BA, THC) and reviewed by all authors (for quality assessment and data extraction form see Additional file 2). We recorded and present study country of origin, study size, male: female ratio or enrolled participants, index test(s) under investigation, reference standard used to define VAP, and test characteristics. Although test characteristics for the index test are not relevant to the aims of this review, we present them herein because several of the index tests are also used as reference standards. Test characteristics are taken directly from the studies or calculated using data contained within the studies. Where multiple test characteristics are presented in the original paper, we selected those highlighted by the original authors or those which reflect the comparison best, or those which indicate the best performance. Where BAL was conducted, we recorded the details of the lavage procedure.

A narrative data synthesis approach was used to report the results from reviewed studies. Due to the large variation in practice, processes, and reference standards, a meta-analysis of diagnostic accuracy was not conducted.

\section{Results}

\section{Studies identified}

The searches identified a total of 2441 articles. Records that were not published in English were translated to English using Google translator. 2263 articles were excluded on the basis of title and abstract and a further 123 on the basis of full-text screening were excluded as not clinically relevant to the inclusion criteria or meeting at least one of the exclusion criteria, leaving 55 articles for quality assessment (see Fig. 1 for PRISMA flow chart).

\section{Quality assessment and data extraction}

Of the 55 studies examined in the quality assessment stage, 11 studies were excluded due to either scored ' 0 ' for the first or the second question or scored less than ' 5 ' out of' 8 ' in total score, leaving 44 studies included in this review [40-83]. All scored were agreed by at least two reviewers and reviewed by the principal investigator (PI). The lowest score assigned to any included study was ' 5 ' out of ' 8 .' Three studies scored 8/8, 24 studies scored $7 / 8,11$ studies scored $6 / 8$, and six studies scored $5 / 8$ (see Table 1).

As expected, all papers suffered from bias in their accuracy estimates of the index test from the use of an imperfect reference standard comparison, a wellknown issue with comparative diagnostic accuracy studies [84]. The results of the quality assessment reviews conducted using the form adopted from CASP diagnostic study checklist showed that five papers [51, 54, 57, 62, 82] suffered from verification bias: not all patients received testing by both the index and the reference standard. In 38 papers [41-47, 49-53, 55-59, $61-68,70,71,73-82]$, the results of the index test could have been influenced by the reference standard result. This means that there was no evidence blinding or the tests being performed independently. The VAP status for all participants in the study was not clearly defined 

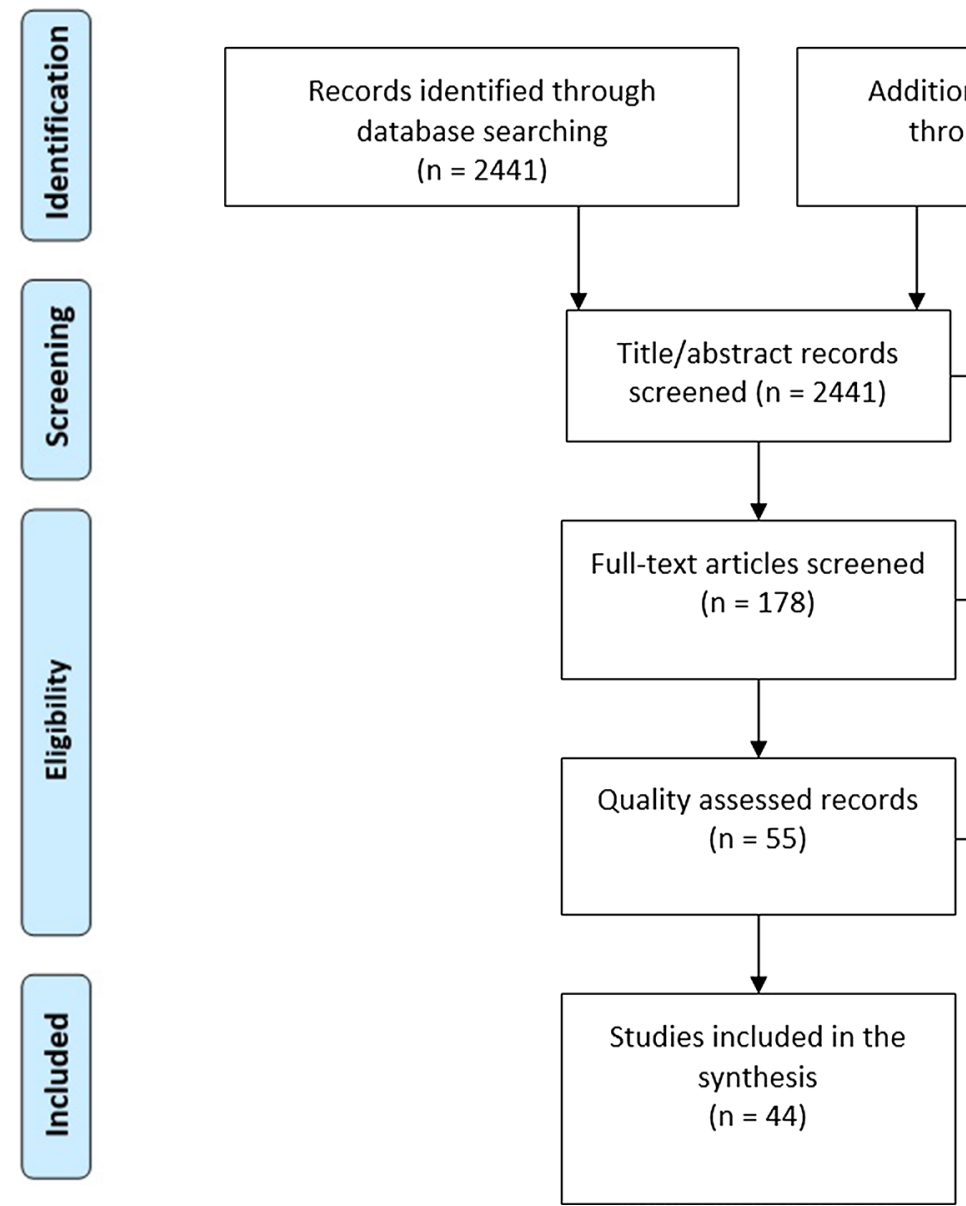

dditional records identified through other sources $(n=0)$
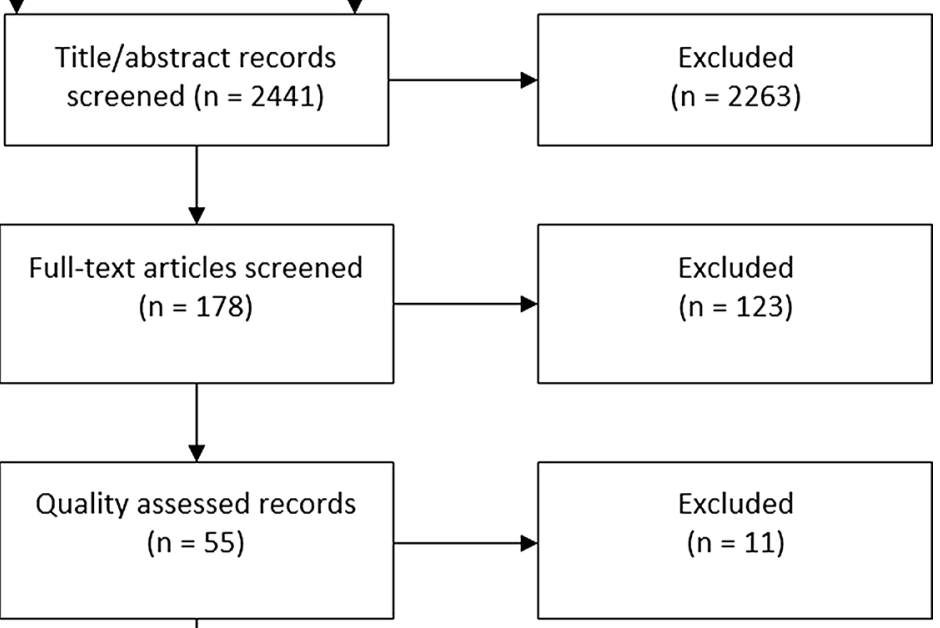

Fig. 1 PRISMA systematic review flow chart. Adapted from: Moher et al. [96]

in two papers $[47,65]$. The methodology description was not described in detail in three papers [40, 45, 82] and the results of the study were not clearly presented in five papers $[46,64,67,69,75]$. There was a lack of certainty regarding the results of the study on 11 occasions $[40,42,43,46,58,64,65,67,68,74,75]$. CASP diagnostic study checklist guide was followed in assessing all points.

The disagreement was solved through discussion between both reviewers on 20 papers, and adjudication of a third reviewer in one paper. Forty-three of the studies were cohort studies (38 of which were prospective studies) and one was a secondary analysis of data from a randomised controlled trial (RCT) [57]. All studies were published between 2008 and 2018 with a wide geographical spread; four studies conducted in the UK [41, 44, 72, $74]$, eight in the USA [40, 45, 47, 50, 56, 62, 67, 75], seven in France [51, 53, 55, 63, 70, 73, 78], five in Netherland $[48,61,66,77,79]$, three each in both China $[52,65,68]$ and Turkey [43, 46, 82], two each in Egypt $[49,76]$, Brazil
$[54,81]$, and Italy [71, 83], and eight in other countries $[42,57-60,64,69,80]$. The median sample size was 180 recruited participants, with the 21 being the lowest [58] and 2080 being the highest number of participants [61] (see Tables 2, 3).

\section{Reference standard}

We did not consider enrolment criteria, including objective criteria for suspicion of VAP, to be part of the reference standard. Out of the 44 included studies, 32 studies (72.7\%) compared an index test with a sole microbiological reference standard (see Table 2). One of these studies did not define which of the studied tests were considered index and which were considered reference [54]. Of the remaining 31 studies, culture of BAL fluid was most commonly used as the reference test, forming at least part of the reference standard in $26(83.8 \%)$ studies [40, 41, 43, $45,48,49,51,55-60,63,65-67,69,70,73-77,79,82]$. BAL culture alone was the sole reference standard in 18 (58.1\%) out of the 31 studies [40, 41, 43, 45, 49, 55, 56, 
Table 1 Quality assessment checklist scores

\begin{tabular}{|c|c|c|c|c|c|c|c|c|c|}
\hline & $\begin{array}{l}\text { 1. Was } \\
\text { there a } \\
\text { clear } \\
\text { questio } \\
\mathrm{n} \text { for } \\
\text { the } \\
\text { study to } \\
\text { addres } \\
\mathrm{s} ?\end{array}$ & $\begin{array}{l}\text { 2. Was } \\
\text { there a } \\
\text { comparis } \\
\text { on with } \\
\text { an } \\
\text { appropria } \\
\text { te } \\
\text { reference } \\
\text { standard } \\
?\end{array}$ & $\begin{array}{l}\text { 3. Did } \\
\text { all } \\
\text { patients } \\
\text { get the } \\
\text { diagnost } \\
\text { ic test } \\
\text { and } \\
\text { referenc } \\
\text { e } \\
\text { standar } \\
\text { d? }\end{array}$ & $\begin{array}{l}\text { 4. Could } \\
\text { the } \\
\text { results } \\
\text { of the } \\
\text { test } \\
\text { have } \\
\text { been } \\
\text { influenc } \\
\text { ed by } \\
\text { the } \\
\text { results } \\
\text { of the } \\
\text { referenc } \\
\text { e } \\
\text { standard } \\
?\end{array}$ & $\begin{array}{l}\text { 5. Is VAP } \\
\text { status of } \\
\text { the } \\
\text { tested } \\
\text { populatio } \\
\text { n clearly } \\
\text { describe } \\
\text { d? }\end{array}$ & $\begin{array}{l}\text { 6. Were } \\
\text { the } \\
\text { methods } \\
\text { for } \\
\text { performi } \\
\text { ng the } \\
\text { test } \\
\text { describe } \\
\text { d in } \\
\text { sufficient } \\
\text { detail? }\end{array}$ & $\begin{array}{l}\text { 7. Were } \\
\text { the } \\
\text { results } \\
\text { clearly } \\
\text { presente } \\
\text { d? }\end{array}$ & $\begin{array}{l}8 . \\
\text { How } \\
\text { sure } \\
\text { are } \\
\text { we } \\
\text { about } \\
\text { the } \\
\text { results } \\
?\end{array}$ & $\begin{array}{l}\text { Total } \\
\text { Scor } \\
\text { e }\end{array}$ \\
\hline $\begin{array}{l}\text { Albert et al. } \\
{[57]}\end{array}$ & $\checkmark$ & $\checkmark$ & $\bar{X}$ & $\mathrm{X}$ & $\checkmark$ & $\checkmark$ & $\checkmark$ & $\checkmark$ & 6 \\
\hline Anand et al. & $\checkmark$ & $\checkmark$ & $\checkmark$ & $\mathrm{X}$ & $\checkmark$ & $\checkmark$ & $\checkmark$ & $\checkmark$ & 7 \\
\hline $\begin{array}{l}\text { Baldesi et } \\
\text { al. [55] }\end{array}$ & $\checkmark$ & $\checkmark$ & $\checkmark$ & $\mathrm{X}$ & $\checkmark$ & $\checkmark$ & $\checkmark$ & $\checkmark$ & 7 \\
\hline $\begin{array}{l}\text { Carvalho et } \\
\text { al. [54] }\end{array}$ & $\checkmark$ & $\checkmark$ & $X$ & $\checkmark$ & $\checkmark$ & $\checkmark$ & $\checkmark$ & $\checkmark$ & 7 \\
\hline $\begin{array}{l}\text { Charles et } \\
\text { al. [53] }\end{array}$ & $\checkmark$ & $\checkmark$ & $\checkmark$ & $X$ & $\checkmark$ & $\checkmark$ & $\checkmark$ & $\checkmark$ & 7 \\
\hline $\begin{array}{l}\text { Chen et al. } \\
\text { [52] }\end{array}$ & $\checkmark$ & $\checkmark$ & $\checkmark$ & $\mathbf{X}$ & $\checkmark$ & $\checkmark$ & $\checkmark$ & $\checkmark$ & 7 \\
\hline $\begin{array}{l}\text { Clavel et al. } \\
{[51]}\end{array}$ & $\checkmark$ & $\checkmark$ & $\mathbf{X}$ & $\mathbf{X}$ & $\checkmark$ & $\checkmark$ & $\checkmark$ & $\checkmark$ & 6 \\
\hline $\begin{array}{l}\text { Conway } \\
\text { Morris et al. } \\
{[74]}\end{array}$ & $\checkmark$ & $\checkmark$ & $\checkmark$ & $X$ & $\checkmark$ & $\checkmark$ & $\checkmark$ & $X$ & 6 \\
\hline $\begin{array}{l}\text { Douglas et } \\
\text { al. [50] }\end{array}$ & $\checkmark$ & $\checkmark$ & $\checkmark$ & $\mathrm{X}$ & $\checkmark$ & $\checkmark$ & $\checkmark$ & $\checkmark$ & 7 \\
\hline $\begin{array}{l}\text { Elmahalawy } \\
\text { et al. [49] }\end{array}$ & $\checkmark$ & $\checkmark$ & $\checkmark$ & $\mathrm{X}$ & $\checkmark$ & $\checkmark$ & $\checkmark$ & $\checkmark$ & 7 \\
\hline $\begin{array}{l}\text { Fujitani et al } \\
\text { [47] }\end{array}$ & $\checkmark$ & $\checkmark$ & $\checkmark$ & $\mathbf{X}$ & $\mathbf{X}$ & $\checkmark$ & $\checkmark$ & $\checkmark$ & 6 \\
\hline Gedik et al. & $\checkmark$ & $\checkmark$ & $\checkmark$ & $\mathbf{X}$ & $\checkmark$ & $\checkmark$ & $\mathrm{X}$ & $\mathbf{X}$ & 5 \\
\hline $\begin{array}{l}\text { Goldberg et } \\
\text { al. [45] }\end{array}$ & $\checkmark$ & $\checkmark$ & $\checkmark$ & $\mathbf{X}$ & $\checkmark$ & $\mathbf{X}$ & $\checkmark$ & $\checkmark$ & 6 \\
\hline $\begin{array}{l}\text { Grover et al. } \\
\text { [44] }\end{array}$ & $\checkmark$ & $\checkmark$ & $\checkmark$ & $\bar{X}$ & $\checkmark$ & $\checkmark$ & $\sigma^{\prime}$ & $\checkmark$ & 7 \\
\hline $\begin{array}{l}\text { Guler et al. } \\
\text { [43] }\end{array}$ & $\checkmark$ & $\checkmark$ & $\checkmark$ & $X$ & $\checkmark$ & $\checkmark$ & $\checkmark$ & $X$ & 6 \\
\hline $\begin{array}{l}\text { Hashimoto } \\
\text { et al. [42] }\end{array}$ & $\checkmark$ & $\checkmark$ & $\checkmark$ & $X$ & $\checkmark$ & $\checkmark$ & $\checkmark$ & $X$ & 6 \\
\hline $\begin{array}{l}\text { Hellyer et } \\
\text { al. [41] }\end{array}$ & $\checkmark$ & $\checkmark$ & $\checkmark$ & $\mathbf{X}$ & $\checkmark$ & $\checkmark$ & $\checkmark$ & $\checkmark$ & 7 \\
\hline $\begin{array}{l}\text { Jackson et } \\
\text { al. [40] }\end{array}$ & $\checkmark$ & $\checkmark$ & $\checkmark$ & $\checkmark$ & $\checkmark$ & $X$ & $\checkmark$ & $X$ & 6 \\
\hline $\begin{array}{l}\text { Jiao et al. } \\
{[65]}\end{array}$ & $\checkmark$ & $\checkmark$ & $\checkmark$ & $X$ & $\mathbf{X}$ & $\checkmark$ & $\checkmark$ & $X$ & 5 \\
\hline $\begin{array}{l}\text { Jovanovic } \\
\text { et al. [64] }\end{array}$ & $\checkmark$ & $\checkmark$ & $\checkmark$ & $\mathbf{X}$ & $\checkmark$ & $\checkmark$ & $\mathbf{X}$ & $X$ & 5 \\
\hline $\begin{array}{l}\text { Jung et al. } \\
{[63]}\end{array}$ & $\checkmark$ & $\checkmark$ & $\checkmark$ & $X$ & $\checkmark$ & $\checkmark$ & $\checkmark$ & $\checkmark$ & 7 \\
\hline $\begin{array}{l}\text { Klompas et } \\
\text { al. [62] }\end{array}$ & $\checkmark$ & $\checkmark$ & $\mathrm{X}$ & $X$ & $\checkmark$ & $\checkmark$ & $\sigma^{\prime}$ & $\checkmark$ & 6 \\
\hline $\begin{array}{l}\text { Klein } \\
\text { Klouwenbe } \\
\text { rg et al. [61] }\end{array}$ & $\checkmark$ & $\checkmark$ & $\checkmark$ & $\mathbf{X}$ & $\checkmark$ & $\checkmark$ & $\checkmark$ & $\checkmark$ & 7 \\
\hline
\end{tabular}

green tick = acceptable quality, red box = unacceptable quality 


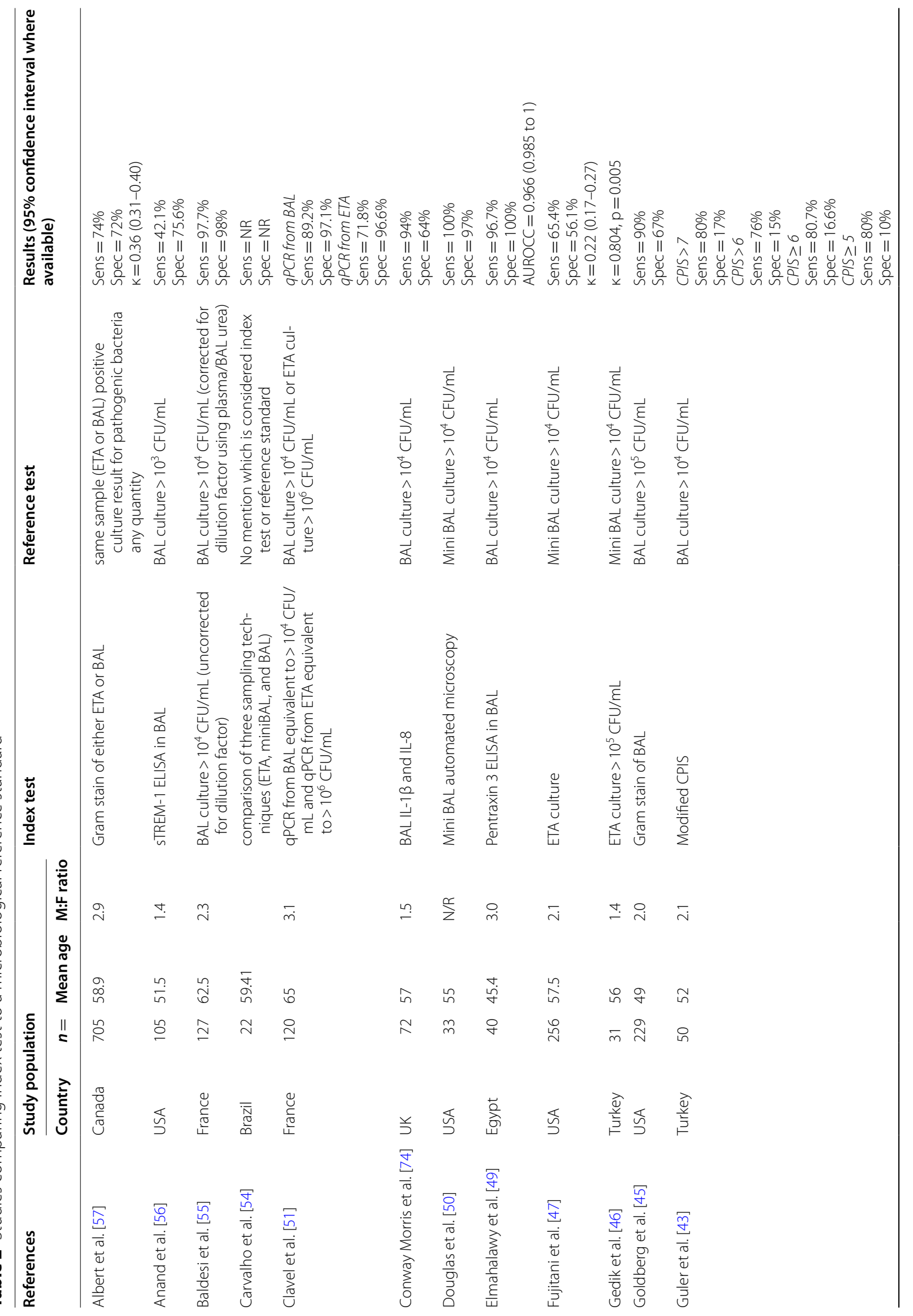




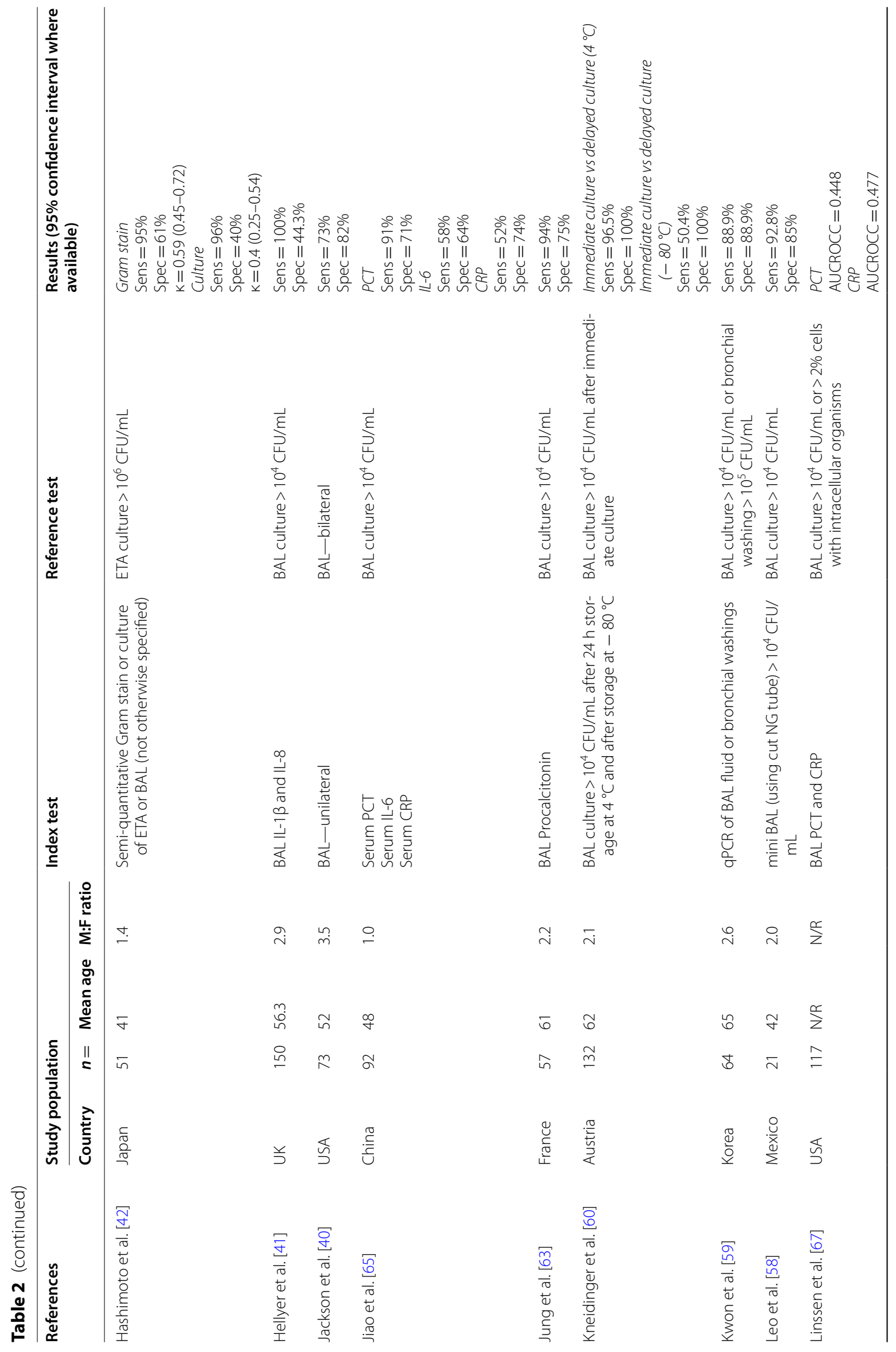




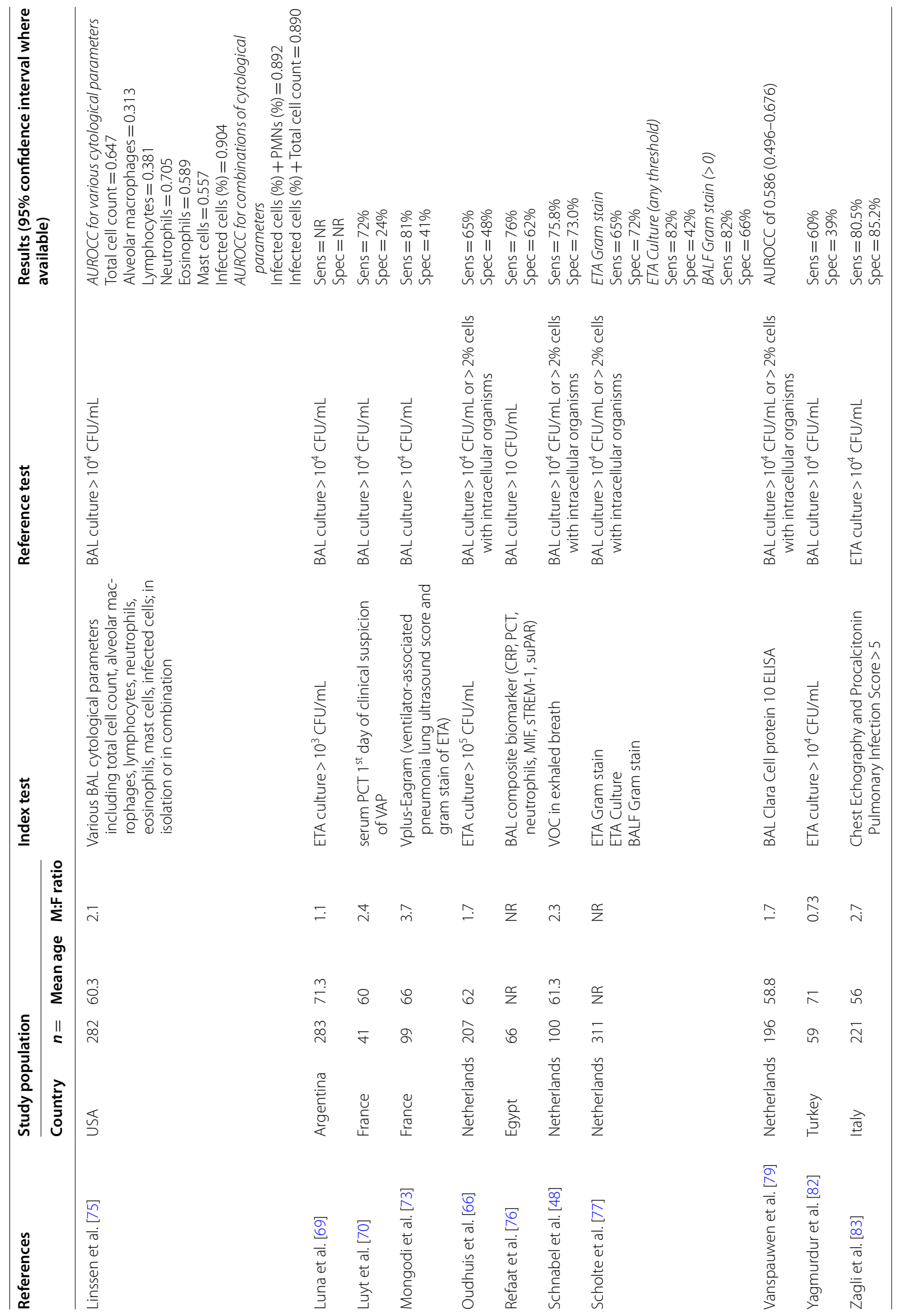




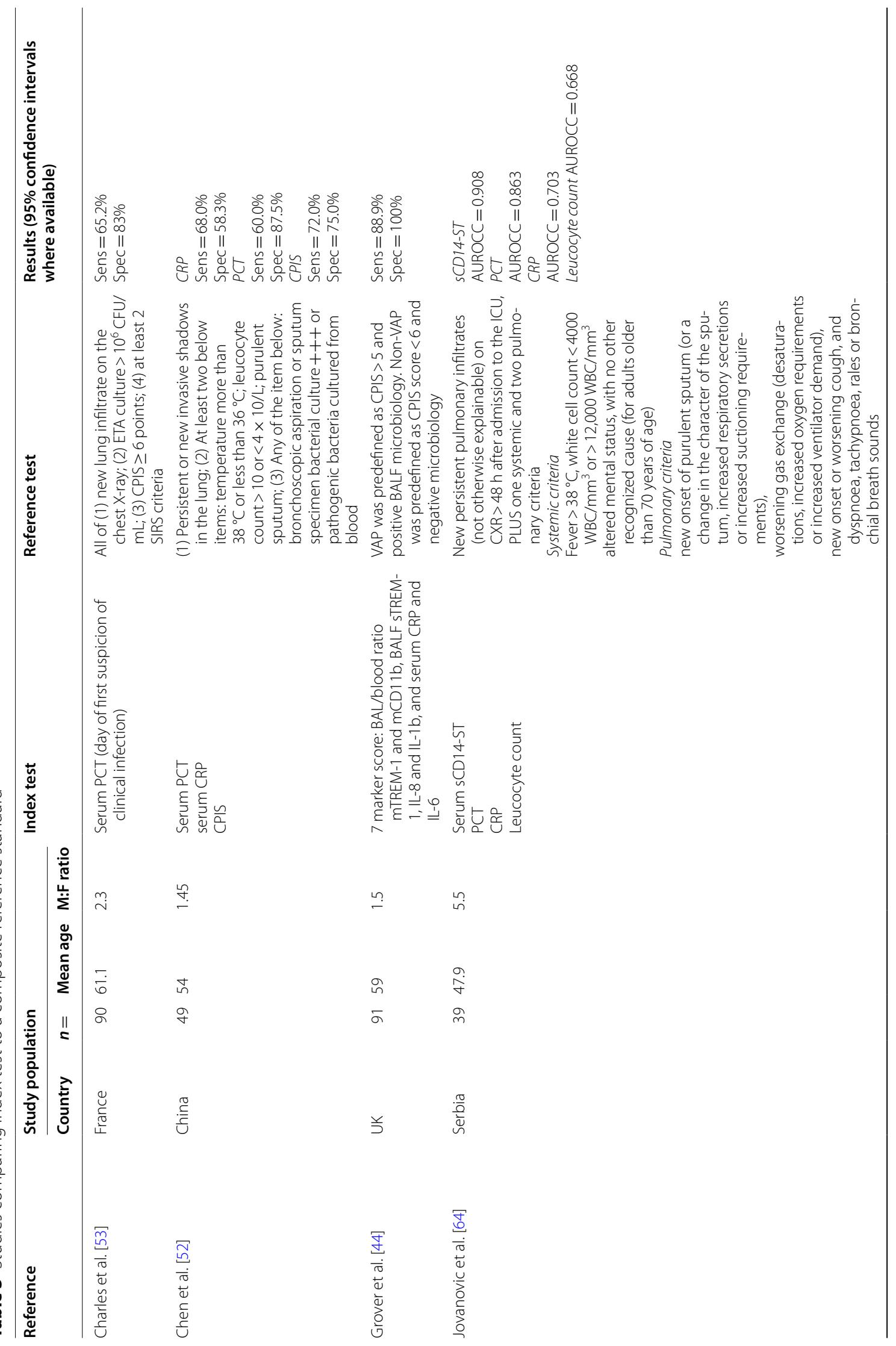




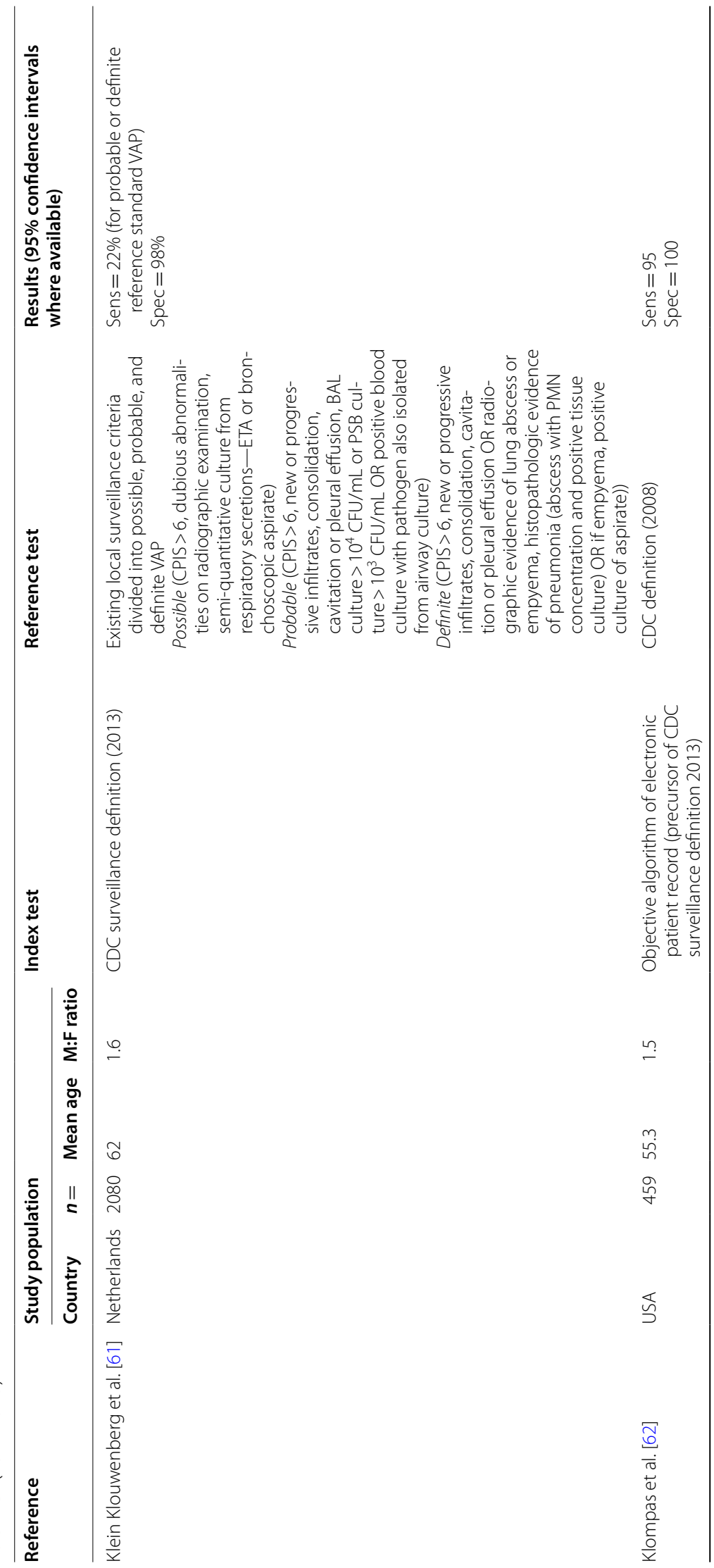




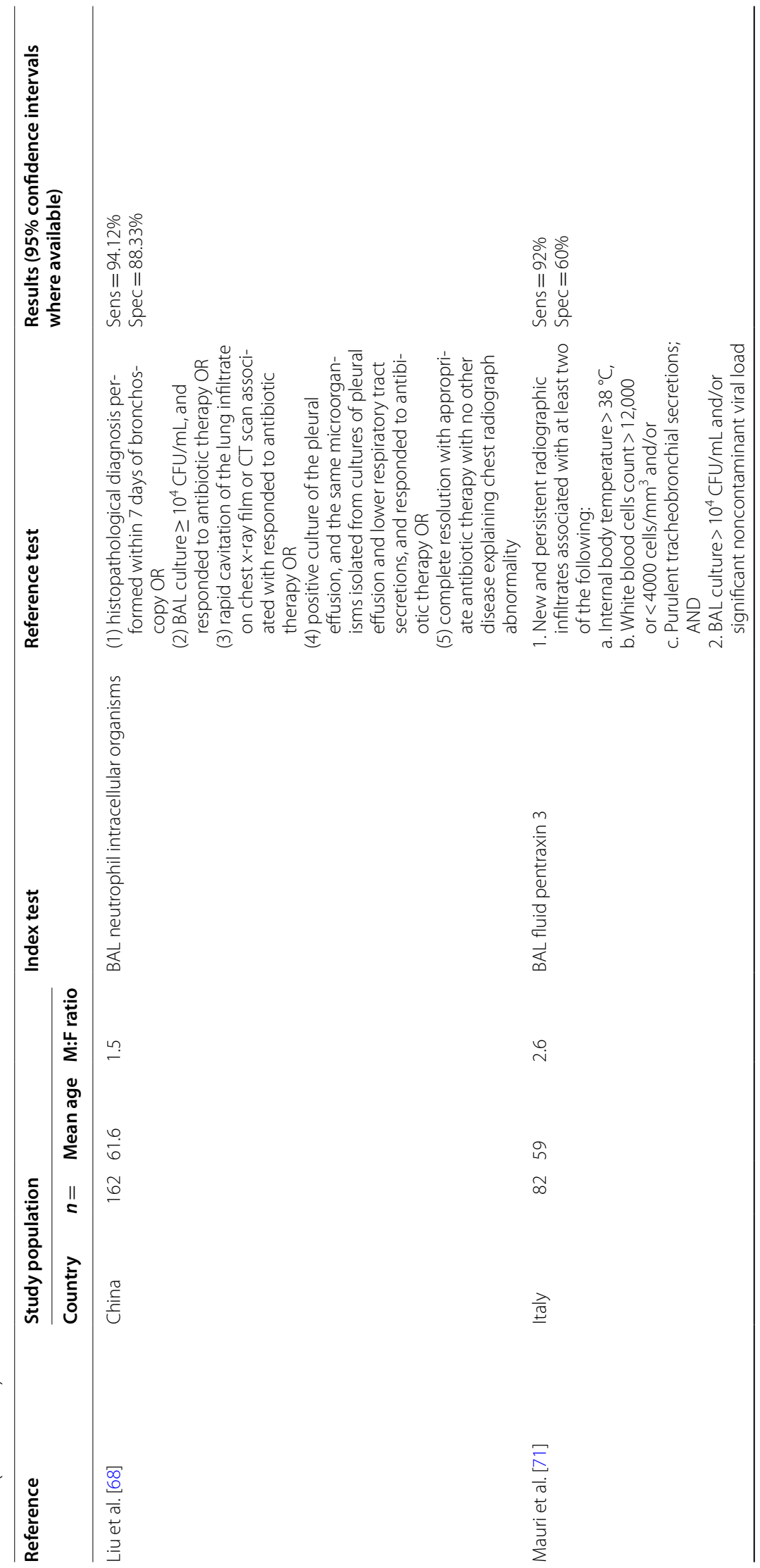




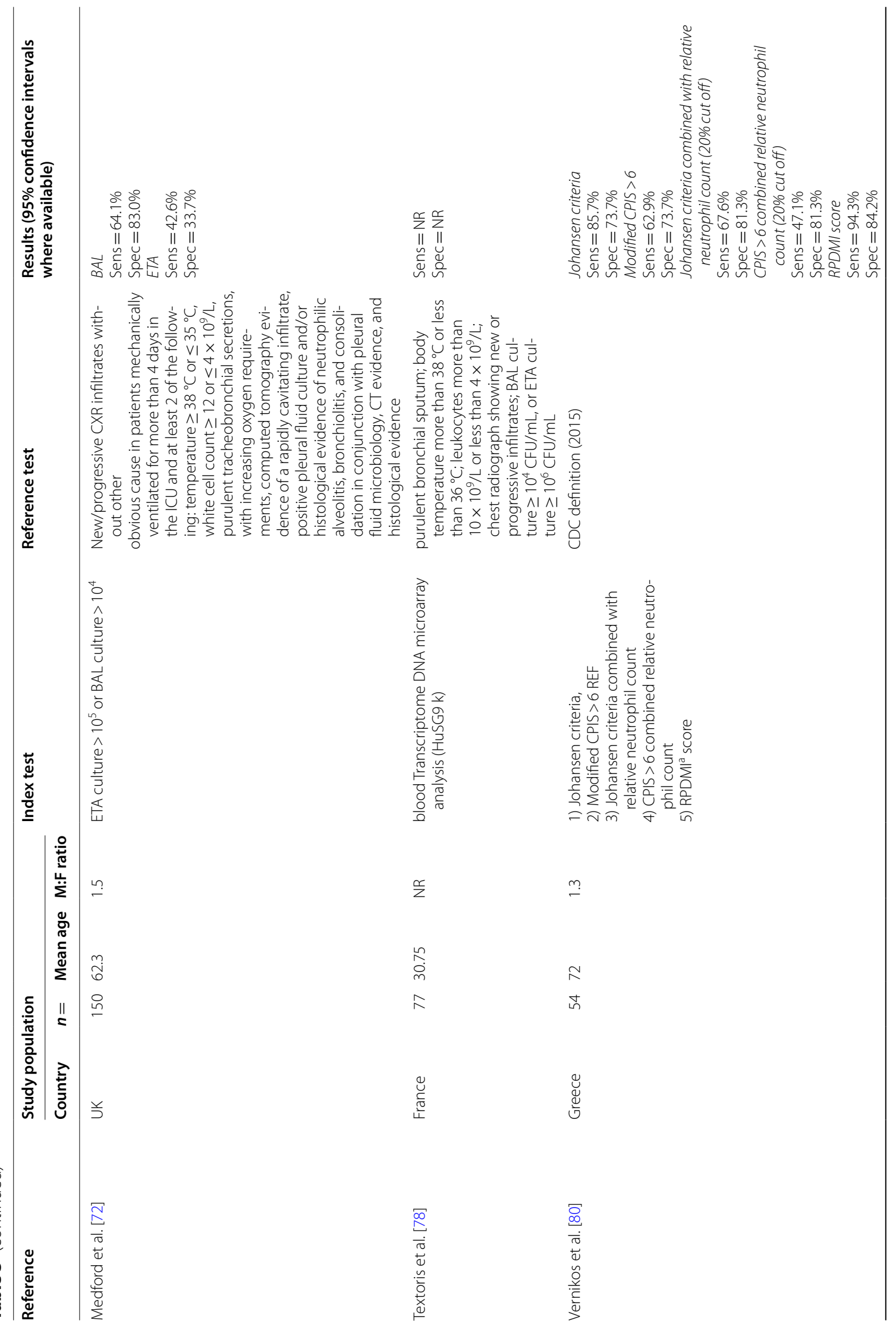




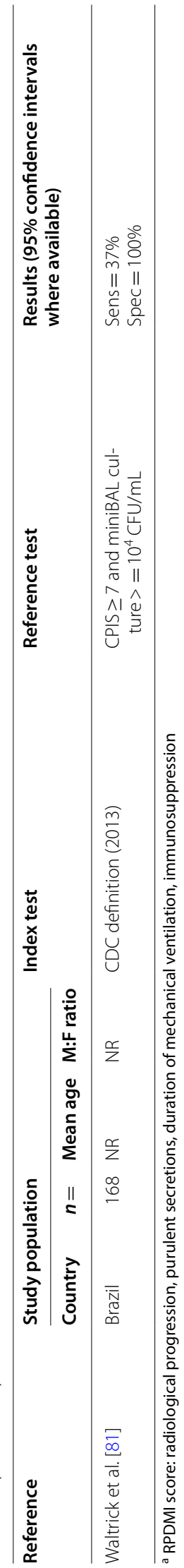


$58,60,63,65,69,70,73-76,82]$. Where used, the BAL culture threshold for positivity included $>10 \mathrm{CFU} / \mathrm{mL}$ [76], $>10^{3} \mathrm{CFU} / \mathrm{mL}$ [56], $>10^{4} \mathrm{CFU} / \mathrm{mL}[40,41,43,49,55$, $58,60,63,65,69,70,73-75,82]$, and $>10^{5} \mathrm{CFU} / \mathrm{mL}$ [45]. Three studies using BAL culture $>10^{4} \mathrm{CFU} / \mathrm{mL}$ added an additional stipulation on BAL culture results: one requiring correction of microbial growth for plasma to $\mathrm{BAL}$ urea ratio [55], one requiring that lavage was bilateral [40], and one specifying culture took place immediately after lavage [60]. BAL culture was used in combination with another criterion regarding assessment of BAL on an additional eight occasions out of the 26 using BAL (30.8\%); five out of these eight (62.5\%) BAL culture or $>2 \%$ lavage cells containing intracellular organisms $[48,66,67,77,79]$, one out of the eight (12.5\%) BAL culture or bronchial washings culture $\left(>10^{5} \mathrm{CFU} / \mathrm{mL}\right)$ [59], and two out of the eight (11.1\%) BAL culture or ETA culture $\left(>10^{6} \mathrm{CFU} / \mathrm{mL}\right.$ [51] or no threshold specified [57]. On the remaining five out of 31 (16.1\%) occasions where BAL culture was not incorporated into the microbiological reference standard, three studies used mini-BAL culture $>10^{4} \mathrm{CFU} / \mathrm{mL}[46,47,50]$, one study used ETA culture $>10^{6} \mathrm{CFU} / \mathrm{mL}$ [42] $\mathrm{m}$, and one study used ETA culture $>10^{4} \mathrm{CFU} / \mathrm{mL}$ [83], as sole reference standards.

Table 3 summarises the remaining 12/44 (27.2\%) studies which compared an index test to a composite reference standard or clinical scoring system $[44,52,53,61$, $62,64,68,71,72,78,80,81]$. An iteration of the CDC VAP definition was used in two out of the 12 studies (16.7\%), one using the 2008 iteration for surveillance of VAP [62] and one using the 2015 iteration for surveillance of VAP (80]. One additional study [64] used a composite reference standard almost identical to the 2008 iteration of the CDC VAP surveillance criteria. The 2008 iteration of the CDC surveillance criteria does not include any microbiological assessment of respiratory samples, and non-culture methods or histopathology may supplant microbiological culture in the 2010 and 2015 iterations of the CDC surveillance criteria [28, 62, 85]. For the remaining nine studies; four out of the nine (44.4\%) explicitly incorporated the clinical pulmonary infection score (CPIS) into a wider set of criteria [44, 53, 61, 81]. Seven out nine $(77.8 \%)$ incorporated radiological assessment $[52,53,64,68,71,72,78]$, eight out of nine (88.9\%) incorporated additional clinical signs and symptoms [44, $52,53,61,71,72,78,81]$ either as part of an existing scoring system such as CPIS or de novo, and all nine studies (100\%) incorporated some microbiological assessment into the combined reference standard $[44,52,53,64$, $68,71,72,78,81]$. In seven of those nine studies (77.8\%) positive microbiology was a mandatory criterion for VAP diagnosis $[44,52,53,64,71,78,81]$, and in two of those nine $(22.2 \%)$, positive microbiological cultures were an optional criterion for VAP diagnosis [68, 72]. Amongst all included studies microbiological assessment did not form any part of the mandatory or optional criteria for VAP diagnosis in only two studies [62, 64], diagnosis of VAP included an optional microbiological assessment component in another two studies (i.e. VAP diagnosis could be made without recourse to microbiological assessment) [68, 72], and in 39 studies microbiological assessment was the sole or a mandatory component [40-53, 55-60, 63-71, 73-79, 81-83]. Four studies incorporated an optional histopathologic element into the reference standard $[61,68,72,80]$, but it was mandatory in none.

Out of all 44 included studies, 37 (84\%) incorporate BAL in either the reference standard or index test [40$51,54-60,63,65-79,81,82]$. Twenty two studies (50\%) included a precise lavage procedure in the methodology $[40,41,43,45,48,51,55-58,60,63,66-69,71,72$, $74-76,82]$. Of these, 14 described an initial discard of aspirated fluid, considered to be uninformative bronchial fluid [40, 41, 43, 51, 57, 58, 60, 63, 68, 69, 71, 72, 74, 82]. The median volume of instilled fluid used to generate the discarded fluid was $20 \mathrm{~mL}$ (range $20 \mathrm{~mL}$ to $50 \mathrm{~mL}$ ). The median total volume of instilled fluid (including that intended for discard) was $150 \mathrm{~mL}$ (range $80 \mathrm{~mL}$ to $200 \mathrm{~mL}$ ).

\section{Discussion}

To the best of our knowledge, this is the first and most comprehensive systematic review aiming to evaluate the reference standard tests used to evaluate novel index tests for suspected VAP since the publication of Rea-Neto and colleagues systematic review of diagnostic methods in 2008 [32]. We reviewed papers comparing a novel index test against a chosen reference standard to identify what reference standards have been used in diagnostic evaluation research for VAP. To deliver a high-quality systematic review, we excluded papers with a high risk of bias and all papers included in this review fulfil at least 5 out of the 8 criteria we included from the CASP checklist.

The microbiological culture was the sole or a component criterion in the vast majority of studies. Overall, the culture of BAL fluid was the most common reference standard, with the most common growth threshold being $>10^{4} \mathrm{CFU} / \mathrm{mL}$. This was occasionally used in combination with another reference standard, such as the demonstration of BAL cells with intracellular organisms exceeding $2 \%$ of the total number of cells. Composite reference standards incorporating a variety of existing clinical scores, existing surveillance definitions, radiological assessments, clinical parameters, and microbiological methods including culture were used in the remaining studies. A large variation in practice, processes, and reference standards were detected, highlighting the 
inconsistency in the current diagnosis of VAP and making a meta-analysis of diagnostic accuracy challenging. Biological, clinical, and statistical heterogeneity makes comparisons across the different studies difficult and subjective. We display a variable and generally good quality of the papers, and the review provides an indication of what has been and is being done in this area globally with respect to the use of reference standard in the diagnostics of VAP. The line between composite criteria and a sole microbiological criterion was often blurred. Many studies in the sole microbiological criterion group had strict objective clinical and radiological enrolment criteria. Where these criteria are applied pre-enrolment and therefore applied to both index tests and reference standards we have not incorporated them into a description of the reference standard.

A key question in diagnostic accuracy research when reference standards are imperfect is whether the reference standard used to assess novel diagnostics should be 'more inclusive' (higher sensitivity, lower specificity) or 'less inclusive' (lower sensitivity, higher specificity). Using microbiological criteria alone exhibits good face validity but risks missing cases of 'true VAP' or including false positives through contamination (although prior specification of clinically suspected VAP reduces this risk). Importantly, both possibilities are potentially strongly influenced by operator technique/expertise, especially for BAL; this contrasts with diagnostics reliant on blood sampling or imaging. BAL culture was the most common microbiological method found in this review. The use of BAL culture is potentially problematic for several reasons. Firstly, in a recent systematic review, when compared to the reference standard of histopathological examination of lung tissue, BAL culture had a sensitivity of $71.1 \%$ and specificity of $79.6 \%$ [86] echoing previous findings that microbiological examination does not correlate well with histopathological examination [32]. Secondly, the timing and nature of prior antibiotic therapy may adversely affect sample positivity [87, 88], although this problem is conceivably solved by incorporating a criterion addressing percentage of host cells containing invading organisms, a measure not affected by prior antibiotic therapy [75]. Thirdly, the BAL procedure itself is not standardised, and the requirements for sample collection are not uniform. Whilst this may have little impact on bacterial growth, a fact confirmed by one of the included studies [55], the variety of studies that utilised bronchial discard may plausibly lead to a variety in sensitivity at detecting the causative pathogenic organism. Sole microbiological criteria also risk introducing cases of 'false VAP' through contamination [87], although this risk is reduced by using distal or protected specimens. Of relevance, the quality and consistency of BAL procedures are likely to be higher in studies than during routine clinical practice, which could further influence its validity.

Using composite criteria may conceivably address the problem of missing cases of 'true VAP', and the number or thresholds of additional criteria is not limited. Additional criteria can be made mandatory to increase specificity or made optional to increase sensitivity. Some studies in this review rely on existing surveillance definitions for VAP or use their own composite standards. The existing surveillance definitions were designed to objectively and reproducibly monitor VAP rates not to identify true VAP in a robustly sensitive and specific manner, although as a quality indicator face validity amongst clinicians is important. Other composite studies incorporated radiological assessments into the reference standard. It has been shown that chest $\mathrm{x}$-ray changes are not considered integral to the diagnosis by many clinicians [89], that the performance characteristics of chest $\mathrm{x}$-ray may not meet the requirements as a diagnostic standard [90-92], and that inter- and intra-observer variability is high in chest $x$-ray assessment $[93,94]$. These issues mean that incorporation of radiology into any novel reference standard should be undertaken with caution. Many studies incorporate clinical signs which plausibly reduces the risk of false positives, and although this makes physiological sense there is minimal evidence to support this. Klompas et al. showed, in the development of the novel CDC VAP surveillance algorithm, that deterioration in oxygenation after a period of stability was associated with clinically important outcomes but the addition of other clinical measures such as abnormal temperature, abnormal white blood cell count, or purulent secretions was not [95]. However, a lack of correlation with clinically important outcomes is not the same as a lack of correlation with a true diagnosis of VAP; this issue is relevant when the decision based on the test relates to a therapy (antibiotic use) rather than prognosis.

No studies relied upon histopathological diagnosis of VAP to confirm the diagnosis. This is not surprising for practical reasons: it cannot be routinely and safely undertaken in all patients with suspected VAP either at the time of the index test or later. Histopathological analysis may also be inaccurate due to sampling artefacts, the lack of representation of a small piece of tissue, and displacement in time from the period of peak infection. It is not possible to provide certainty about the appropriate reference standard in diagnostic evaluation research for VAP following this systematic review, which simply identifies the methods chosen by researchers and confirms the lack of a standardised approach. Researchers must decide whether it is more important to be 'more inclusive' or 'less inclusive', and future comparisons may wish to 
employ the strategy deployed by one of the studies in this review [61]: using a graded certainty of VAP from possible to probable to definite using a composite definition.

There are three main limitations to our review. Firstly, in order to be diagnosed with VAP, a patient must be at risk of VAP, and there is no standard definition for patients at risk. For the purposes of this study, we defined those at risk of VAP as those who have undergone more than $48 \mathrm{~h}$ of mechanical ventilation. Secondly, many included studies enrolled only patients with suspected VAP, and this means many listed reference standards must be prefixed with "clinically suspected VAP". This level of clinical suspicion was not systematically collected by us. This is particularly noteworthy in considering the reference standards listed in Table 3. Thirdly, although data extraction for this review was completed before the impact of Coronavirus Disease 2019 (COVID-19), the pandemic nonetheless interfered with the delivery time of this review.

\section{Conclusion}

BAL culture with a microbiological growth threshold of $>10^{4} \mathrm{CFU} / \mathrm{mL}$ is the commonest reference standard used to examine the utility of a novel index test for VAP amongst patients who are at risk for and clinically suspected of VAP. Composite reference standards were used in approximately $25 \%$ of reviewed studies. Nearly all reference standards for VAP identified in this review required some microbiological confirmation of infection. The studies identified in this review highlight the need for a standardised approach to diagnosis VAP which may include the development of a data-driven composite reference standard from large cohort studies.

\footnotetext{
Abbreviations

BAL: Broncho-alveolar lavage; CDC: Centers for disease control and prevention; CC-10: Clara cell protein 10; COVID-19: Coronavirus Disease 2019; CASP: Critical appraisal skills programme; CBA: Cytometric bead array; ETA: Endotracheal aspirates; ECDC: European centre for disease prevention and control; GC-tofMS: Gas chromatography time-of-flight mass spectrometry; GS: Gram's stain; ITU: Intensive therapy unite; LUS: Lung ultrasound; MeSH: Medical subject headings; CPIS: Modified clinical pulmonary infection score; NHSN/CDC: National healthcare safety network/Center for disease control and prevention; PCR: Polymerase chain reaction; PSB: Protected specimen brush; SQ: Semi quantitative; PCT: Serum procalcitonin; STREM-1:Type 1 soluble triggering receptor expressed on myeloid cells; U/S: Ultrasound; VAE: Ventilator-associated events; VAP: Ventilator-associated pneumonia; VOCs: Volatile organic compounds.
}

\section{Supplementary Information}

The online version contains supplementary material available at https://doi. org/10.1186/s12890-021-01560-0.
Additional file 1. MEDLINE search example.

Additional file 2. Quality assessment and data extraction form.

\section{Acknowledgements}

Not applicable.

\section{Authors' contributions}

BA and AJA designed the review, and BA led the project. All authors contribute and approve the review design and search strategy. BA, PM, and JG conducted the title/abstract screening. The quality assessment and data extraction were conducted by BA, THC, PM, ARA, SG, JS, WSJ, BCL, AW, and MC. The data and results were summarized by BA, AJA, THC, SG, JS, WSJ, BCL, AW, $M C$, interpreted by THC and BA, reviewed by KD and TSW, and approved by all authors. The manuscript was drafted BA and THC, checked by KD and TSW and read and approved by all authors. All authors read and approved the final manuscript.

\section{Funding}

This study was funded by Combating Antibiotic-Resistant Bacteria Biopharmaceutical Accelerator (CARB-X), https://carb-X.org, award Number 4500003353. AJA, JS, WJS, CL and AW were supported by the National Institute for Health Research Newcastle In Vitro Diagnostics Co-operative. The views expressed are those of the author(s) and not necessarily those of the National Institute for Health Research, the National Health Services or the Department of Health and Social Care.

\section{Availability of data and materials}

The datasets used and/or analysed during the current study are available from the corresponding author on reasonable request.

\section{Declarations}

Ethics approval and consent to participate

Not applicable.

Consent to publish

Not applicable.

\section{Competing interests}

The authors declare that they have no competing interests.

\section{Author details}

${ }^{1}$ College of Medicine and Health Sciences, Khalifa University, PO Box 127788, Abu Dhabi, UAE. ${ }^{2}$ School of Health and Life Science, University of Northumbria, Newcastle upon Tyne, UK. ${ }^{3}$ NIHR Newcastle In Vitro Diagnostics Co-operative, Translational and Clinical Research Institute, Newcastle University, Newcastle upon Tyne, UK. ${ }^{4}$ Translational Healthcare Technologies Group, Centre for Inflammation Research, Queen's Medical Research Institute, University of Edinburgh, Edinburgh, UK. ${ }^{5}$ York Health Economics Consortium, Enterprise House, Innovation Way, University of York, York, UK. ${ }^{6}$ NIHR Newcastle In Vitro Diagnostics Co-operative, The Newcastle Upon Tyne Hospitals NHS Foundation Trust, Newcastle upon Tyne, UK. ${ }^{7}$ Laboratory Medicine, Newcastle-UponTyne Hospitals Foundation Trust, Newcastle upon Tyne, UK. ${ }^{8}$ Edinburgh Critical Care Research Group, University of Edinburgh, Edinburgh, UK.

Received: 11 March 2021 Accepted: 2 June 2021

Published online: 09 June 2021

\section{References}

1. Craven TH, Wojcik G, McCoubrey J, Brooks O, Grant E, Keating S, et al. Ventilator-associated pneumonia surveillance using two methods. J Hosp Infect. 2020;104(4):522-8.

2. Fang X, Mei Q, Fan X, Zhu C, Yang T, Zhang L, et al. Diagnostic value of metagenomic next-generation sequencing for the detection of pathogens in bronchoalveolar lavage fluid in ventilator-associated pneumonia patients. Front Microbiol. 2020;11:599756. 
3. Keyt H, Faverio P, Restrepo MI. Prevention of ventilator-associated pneumonia in the intensive care unit: a review of the clinically relevant recent advancements. Indian J Med Res. 2014;139(6):814-21.

4. Steen J, Vansteelandt S, De Bus L, Depuydt P, Gadeyne B, Benoit DD, et al. Attributable mortality of ventilator-associated pneumonia: replicating findings, revisiting methods. Ann Am Thorac Soc. 2020;18(5):830-7.

5. Colombo SM, Palomeque AC, Li BG. The zero-VAP sophistry and controversies surrounding prevention of ventilator-associated pneumonia. Intensive Care Med. 2020;46(2):368-71.

6. Keneally RJ, Peterson TJ, Benjamin JR, Hawkins K, Davison D. Making ventilator associated pneumonia rate a meaningful quality marker. J Intensive Care Med. 2020. https://doi.org/10.1177/0885066620952763.

7. Vincent JL, Bihari DJ, Suter PM, Bruining HA, White J, Nicolas-Chanoin $\mathrm{MH}$, et al. The prevalence of nosocomial infection in intensive care units in Europe. Results of the European Prevalence of Infection in Intensive Care (EPIC) Study. EPIC International Advisory Committee. JAMA. 1995;274(8):639-44.

8. Rello J, Ollendorf DA, Oster G, Vera-Llonch M, Bellm L, Redman R, et al. Epidemiology and outcomes of ventilator-associated pneumonia in a large US database. Chest. 2002;122(6):2115-21.

9. Kollef $\mathrm{MH}$, Hamilton CW, Ernst FR. Economic impact of ventilatorassociated pneumonia in a large matched cohort. Infect Control Hosp Epidemiol. 2012;33(3):250-6.

10. Luckraz H, Manga N, Senanayake EL, Abdelaziz M, Gopal S, Charman SC, et al. Cost of treating ventilator-associated pneumonia post cardiac surgery in the National Health Service: Results from a propensity-matched cohort study. J Intensive Care Soc. 2018;19(2):94-100.

11. Fagon JY, Chastre J, Hance AJ, Montravers P, Novara A, Gibert C. Nosocomial pneumonia in ventilated patients: a cohort study evaluating attributable mortality and hospital stay. Am J Med. 1993;94(3):281-8.

12. Heyland DK, Cook DJ, Griffith L, Keenan SP, Brun-Buisson C. The attributable morbidity and mortality of ventilator-associated pneumonia in the critically ill patient. The Canadian Critical Trials Group. Am J Respir Crit Care Med. 1999;159(4 Pt 1):1249-56.

13. Bekaert M, Timsit J-F, Vansteelandt S, Depuydt P, Vésin A, GarrousteOrgeas $M$, et al. Attributable mortality of ventilator-associated pneumonia: a reappraisal using causal analysis. Am J Respir Crit Care Med. 2011;184(10):1133-9.

14. Ego A, Preiser J-C, Vincent J-L. Impact of diagnostic criteria on the incidence of ventilator-associated pneumonia. Chest. 2015;147(2):347-55.

15. Estella A, Alvarez-Lerma F. Should the diagnosis of ventilator associated pneumonia be improved? Med Intensiva. 2011;35(9):578-82.

16. Ali HS, Khan FY, George S, Shaikh N, Al-Ajmi J. Epidemiology and outcome of ventilator-associated pneumonia in a heterogeneous ICU population in Qatar. Biomed Res Int. 2016;2016:8231787.

17. Papazian L, Klompas M, Luyt C-E. Ventilator-associated pneumonia in adults: a narrative review. Intensive Care Med. 2020;46(5):888-906.

18. Skrupky LP, McConnell K, Dallas J, Kollef MH. A comparison of ventilatorassociated pneumonia rates as identified according to the National Healthcare Safety Network and American College of Chest Physicians criteria. Crit Care Med. 2012;40(1):281-4.

19. Hyllienmark P, Gårdlund B, Persson J-O, Ekdahl K. Nosocomial pneumonia in the ICU: a prospective cohort study. Scand J Infect Dis. 2007;39(8):676-82.

20. Tejerina E, Frutos-Vivar F, Restrepo Ml, Anzueto A, Abroug F, Palizas F, et al. Incidence, risk factors, and outcome of ventilator-associated pneumonia. J Crit Care. 2006;21(1):56-65.

21. Cook DJ, Walter SD, Cook RJ, Griffith LE, Guyatt GH, Leasa D, et al. Incidence of and risk factors for ventilator-associated pneumonia in critically ill patients. Ann Intern Med. 1998;129(6):433-40.

22. Kollef MH. Ventilator-associated pneumonia. A multivariate analysis. JAMA. 1993;270(16):1965-70.

23. Kappstein I, Schulgen G, Beyer U, Geiger K, Schumacher M, Daschner FD. Prolongation of hospital stay and extra costs due to ventilator-associated pneumonia in an intensive care unit. Eur J Clin Microbiol Infect Dis. 1992;11(6):504-8.

24. Rello J, Quintana E, Ausina V, Castella J, Luquin M, Net A, et al. Incidence, etiology, and outcome of nosocomial pneumonia in mechanically ventilated patients. Chest. 1991;100(2):439-44.

25. Dudeck MA, Horan TC, Peterson KD, Allen-Bridson K, Morrell G, Pollock DA, et al. National Healthcare Safety Network (NHSN) Report, data summary for 2010, device-associated module. Am J Infect Control. 2011;39(10):798-816.

26. Suetens C, Morales I, Savey A, Palomar M, Hiesmayr M, Lepape A, et al. European surveillance of ICU-acquired infections (HELICS-ICU): methods and main results. J Hosp Infect. 2007;65(Suppl 2):171-3.

27. De Bus L, Gadeyne B, Steen J, Boelens J, Claeys G, Benoit D, et al. A complete and multifaceted overview of antibiotic use and infection diagnosis in the intensive care unit: results from a prospective four-year registration. Crit Care. 2018;22(1):241.

28. Craven TH, Wojcik G, McCoubrey J, Brooks O, Grant E, Reilly J, et al. Lack of concordance between ECDC and CDC systems for surveillance of ventilator associated pneumonia. Intensive Care Med. 2018;44(2):265-6.

29. Martin-Loeches I, Torres A, Rinaudo M, Terraneo S, de Rosa F, Ramirez $\mathrm{P}$, et al. Resistance patterns and outcomes in intensive care unit (ICU)-acquired pneumonia. Validation of European Centre for Disease Prevention and Control (ECDC) and the Centers for Disease Control and Prevention (CDC) classification of multidrug resistant organisms. J Infect. 2015;70(3):213-22.

30. Baselski V, Klutts JS, Baselski V, Klutts JS. Quantitative cultures of bronchoscopically obtained specimens should be performed for optimal management of ventilator-associated pneumonia. J Clin Microbiol. 2013;51(3):740-4.

31. Torres A, Niederman MS, Chastre J, Ewig S, Fernandez-Vandellos $P_{\text {, }}$ Hanberger $\mathrm{H}$, et al. International ERS/ESICM/ESCMID/ALAT guidelines for the management of hospital-acquired pneumonia and ventilatorassociated pneumonia: Guidelines for the management of hospitalacquired pneumonia (HAP)/ventilator-associated pneumonia (VAP) of the European Respiratory Society (ERS), European Society of Intensive Care Medicine (ESICM), European Society of Clinical Microbiology and Infectious Diseases (ESCMID) and Asociación Latinoamericana del Tórax (ALAT). Eur Respir J. 2017;50(3):1700582. https://doi.org/10.1183/13993 003.00582-2017.

32. Rea-Neto A, Youssef NCM, Tuche F, Brunkhorst F, Ranieri VM, Reinhart K, et al. Diagnosis of ventilator-associated pneumonia: a systematic review of the literature. Crit Care. 2008;12(2):R56.

33. Al-Omari B, McMeekin P, Gray J, Aleen J, Dhaliwal K, Walsh T, et al. Protocol for systematic review of studies investigating ventilator-associated pneumonia(VAP) diagnostic procedures in secondary care [Internet]. PROSPERO; CRD42019125449. 2019. https://www.crd.york.ac.uk/prosp ero/display_record.php?RecordID=125449. Cited 24 Nov 2020.

34. https://casp-uk.net/wp-content/uploads/2018/01/CASP-DiagnosticChecklist-2018.pdf [Internet]. https://casp-uk.net/wp-content/uploads/ 2018/01/CASP-Diagnostic-Checklist-2018.pdf. Cited 24 Nov 2020.

35. Ma L-L, Wang Y-Y, Yang Z-H, Huang D, Weng H, Zeng X-T. Methodological quality (risk of bias) assessment tools for primary and secondary medical studies: what are they and which is better? Mil Med Res. 2020;7(1):7.

36. Zeng X, Zhang Y, Kwong JSW, Zhang C, Li S, Sun F, et al. The methodological quality assessment tools for preclinical and clinical studies, systematic review and meta-analysis, and clinical practice guideline: a systematic review. J Evid Based Med. 2015;8(1):2-10.

37. Williams P, Bond CM, Burton C, Murchie P. A systematic review of the use, quality and effects of pelvic examination in primary care for the detection of gynaecological cancer. J Obstet Gynaecol. 2018;38(5):737.

38. Gomes PTM, Lima LHL, Bueno MKG, Araújo LA, Souza NM. Autism in Brazil: a systematic review of family challenges and coping strategies. J Pediatr (Rio J). 2015;91(2):111-21.

39. Smith T, Cross J, Poland F, Clay F, Brookes A, Maidment I, et al. Systematic review investigating multi-disciplinary team approaches to screening and early diagnosis of dementia in primary care-what are the positive and negative effects and who should deliver it? Curr Alzheimer Res. 2018;15(1):5-17.

40. Jackson S-R, Ernst NE, Mueller EW, Butler KL. Utility of bilateral bronchoalveolar lavage for the diagnosis of ventilator-associated pneumonia in critically ill surgical patients. Am J Surg. 2008;195(2):159-63.

41. Hellyer TP, Morris AC, McAuley DF, Walsh TS, Anderson NH, Singh S, et al. Diagnostic accuracy of pulmonary host inflammatory mediators in the exclusion of ventilator-acquired pneumonia. Thorax. 2015;70(1):41-7.

42. Hashimoto S, Shime N. Evaluation of semi-quantitative scoring of Gram staining or semi-quantitative culture for the diagnosis of ventilator-associated pneumonia: a retrospective comparison with quantitative culture. J Intensive Care. 2013;1(1):2. 
43. Guler E, Kahveci F, Akalin H, Sinirtas M, Bayram S, Ozcan B. Evaluation of a clinical pulmonary infection score in the diagnosis of ventilator-associated pneumonia. SV. 2012;7(1):32-7.

44. Grover V, Pantelidis P, Soni N, Takata M, Shah PL, Wells AU, et al. A biomarker panel (Bioscore) incorporating monocytic surface and soluble TREM-1 has high discriminative value for ventilator-associated pneumonia: a prospective observational study. PLoS ONE. 2014;9(10):e109686.

45. Goldberg AE, Malhotra AK, Riaz OJ, Aboutanos MB, Duane TM, Borchers $C T$, et al. Predictive value of broncho-alveolar lavage fluid Gram's stain in the diagnosis of ventilator-associated pneumonia: a prospective study. J Trauma. 2008;65(4):871-6 (discussion 876).

46. Gedik H, Yahyaoğlu M, Fincancı M. The diagnostic accuracy of endotracheal aspiration and mini-bronchoalveolar lavage cultures in the diagnosis of ventilator associated pneumonia. Nobel Med. 2010;6:68-74.

47. Fujitani S, Cohen-Melamed MH, Tuttle RP, Delgado E, Taira Y, Darby JM. Comparison of semi-quantitative endotracheal aspirates to quantitative non-bronchoscopic bronchoalveolar lavage in diagnosing ventilatorassociated pneumonia. Respir Care. 2009;54(11):1453-61.

48. Schnabel R, Fijten R, Smolinska A, Dallinga J, Boumans M-L, Stobberingh $E$, et al. Analysis of volatile organic compounds in exhaled breath to diagnose ventilator-associated pneumonia. Sci Rep. 2015;5:17179.

49. Elmahalawy II, Ammar AS, Fathy WM, Salama AE, Mokhtar WS. Pentraxin 3 as an early marker in diagnosis of ventilator associated pneumonia. Egypt J Chest Dis Tuberc. 2017:66(4):709-12.

50. Douglas IS, Price CS, Overdier KH, Wolken RF, Metzger SW, Hance $K R$, et al. Rapid automated microscopy for microbiological surveillance of ventilator-associated pneumonia. Am J Respir Crit Care Med. 2015;191(5):566-73.

51. Clavel M, Barraud O, Moucadel V, Meynier F, Karam E, Ploy MC, et al. Molecular quantification of bacteria from respiratory samples in patients with suspected ventilator-associated pneumonia. Clin Microbiol Infect. 2016;22(9):812.e1-812.e7.

52. Chen C, Yan M, Hu C, Lv X, Zhang H, Chen S. Diagnostic efficacy of serum procalcitonin, C-reactive protein concentration and clinical pulmonary infection score in Ventilator-Associated Pneumonia. Med Sci (Paris). 2018;34((Focus issue F1)):26-32.

53. Charles PE, Kus E, Aho S, Prin S, Doise J-M, Olsson N-O, et al. Serum procalcitonin for the early recognition of nosocomial infection in the critically ill patients: a preliminary report. BMC Infect Dis. 2009;9:49.

54. de Carvalho EM, Massarollo PCB, Levin AS, Isern MRM, Pereira WL, Abdala E, et al. Comparative study of etiological diagnosis of nosocomial pneumonia. Braz J Infect Dis. 2008;12(1):67-74.

55. Baldesi O, Michel F, Guervilly C, Embriaco N, Granfond A, La Scola B, et al. Bacterial ventilator-associated pneumonia: bronchoalveolar lavage results are not influenced by dilution. Intensive Care Med. 2009;35(7):1210-5.

56. Anand NJ, Zuick S, Klesney-Tait J, Kollef MH. Diagnostic implications of soluble triggering receptor expressed on myeloid cells-1 in BAL fluid of patients with pulmonary infiltrates in the ICU. Chest. 2009;135(3):641-7.

57. Albert M, Friedrich JO, Adhikari NKJ, Day AG, Verdant C, Heyland DK, et al. Utility of Gram stain in the clinical management of suspected ventilatorassociated pneumonia. Secondary analysis of a multicenter randomized trial. J Crit Care. 2008;23(1):74-81.

58. Leo A, Galindo-Galindo J, Folch E, Guerrero A, Bosques F, Mercado R, et al. Comparison of bronchoscopic bronchoalveolar lavage vs blind lavage with a modified nasogastric tube in the etiologic diagnosis of ventilatorassociated pneumonia. Med Intensiva. 2008;32(3):115-20.

59. Kwon S-J, Jeon T, Seo D, Na M, Choi E-G, Son J-W, et al. Quantitative PCR for etiologic diagnosis of methicillin-resistant Staphylococcus aureus pneumonia in Intensive Care Unit. Tuberc Respir Dis (Seoul). 2012;72(3):293-301.

60. Kneidinger N, Warszawska J, Schenk P, Fuhrmann V, Bojic A, Hirschl A, et al. Storage of bronchoalveolar lavage fluid and accuracy of microbiologic diagnostics in the ICU: a prospective observational study. Crit Care. 2013;17(4):R135.

61. Klein Klouwenberg PMC, van Mourik MSM, Ong DSY, Horn J, Schultz MJ, Cremer OL, et al. Electronic implementation of a novel surveillance paradigm for ventilator-associated events. Feasibility and validation. Am J Respir Crit Care Med. 2014;189(8):947-55.

62. Klompas M, Kleinman K, Platt R. Development of an algorithm for surveillance of ventilator-associated pneumonia with electronic data and comparison of algorithm results with clinician diagnoses. Infect Control Hosp Epidemiol. 2008;29(1):31-7.

63. Jung B, Embriaco N, Roux F, Forel J-M, Demory D, Allardet-Servent J, et al. Microbiogical data, but not procalcitonin improve the accuracy of the clinical pulmonary infection score. Intensive Care Med. 2010;36(5):790-8.

64. Jovanovic B, Djuric O, Markovic-Denic L, Isakovic A, Doklestic K, Stankovic $\mathrm{S}$, et al. Prognostic value of presepsin (soluble CD14-subtype) in diagnosis of ventilator-associated pneumonia and sepsis in trauma patients. VSP. 2018;75(10):968-77.

65. Jiao J, Wang M, Zhang J, Shen K, Liao X, Zhou X. Procalcitonin as a diagnostic marker of ventilator-associated pneumonia in cardiac surgery patients. Exp Ther Med. 2015;9(3):1051-7.

66. Oudhuis GJ, Beuving J, Bergmans D, Stobberingh EE, ten Velde G, Linssen CF, et al. Soluble Triggering Receptor Expressed on Myeloid cells-1 in bronchoalveolar lavage fluid is not predictive for ventilator-associated pneumonia. Intensive Care Med. 2009;35(7):1265-70.

67. Linssen CFM, Bekers O, Drent M, Jacobs JA. C-reactive protein and procalcitonin concentrations in bronchoalveolar lavage fluid as a predictor of ventilator-associated pneumonia. Ann Clin Biochem. 2008;45(Pt 3):293-8.

68. Liu C, Du Z, Zhou Q, Hu B, Li Z, Yu L, et al. Microscopic examination of intracellular organisms in bronchoalveolar lavage fluid for the diagnosis of ventilator-associated pneumonia: a prospective multi-center study. Chin Med J. 2014;127(10):1808-13.

69. Luna CM, Sarquis S, Niederman MS, Sosa FA, Otaola M, Bailleau N, et al. Is a strategy based on routine endotracheal cultures the best way to prescribe antibiotics in ventilator-associated pneumonia? Chest. 2013;144(1):63-71.

70. Luyt C-E, Combes A, Reynaud C, Hekimian G, Nieszkowska A, Tonnellier M, et al. Usefulness of procalcitonin for the diagnosis of ventilator-associated pneumonia. Intensive Care Med. 2008;34(8):1434-40.

71. Mauri T, Coppadoro A, Bombino M, Bellani G, Zambelli V, Fornari C, et al. Alveolar pentraxin 3 as an early marker of microbiologically confirmed pneumonia: a threshold-finding prospective observational study. Crit Care. 2014;18(5):562.

72. Medford ARL, Husain SA, Turki HM, Millar AB. Diagnosis of ventilatorassociated pneumonia. J Crit Care. 2009;24(3):473.e1-6.

73. Mongodi S, Via G, Girard M, Rouquette I, Misset B, Braschi A, et al. Lung ultrasound for early diagnosis of ventilator-associated pneumonia. Chest 2016;149(4):969-80.

74. Conway Morris A, Kefala K, Wilkinson TS, Moncayo-Nieto OL, Dhaliwal $K$, Farrell L, et al. Diagnostic importance of pulmonary interleukin1 beta and interleukin-8 in ventilator-associated pneumonia. Thorax. 2010;65(3):201-7.

75. Linssen CFM, Jacobs JA, Schouten JSAG, van Mook WNKA, Ramsay G, Drent M. Influence of antibiotic therapy on the cytological diagnosis of ventilator-associated pneumonia. Intensive Care Med. 2008;34(5):865-72.

76. Refaat A, Affara N, Abdel-fatah W, Hussein T, El-gerbi M. Diagnostic accuracy of inflammatory biomarkers in bronchoalveolar lavage from patients with ventilator-associated pneumonia. Egypt J Chest Dis Tuberc. 2014;63(3):723-30.

77. Scholte JBJ, van Dessel HA, Linssen CFM, Bergmans DCJJ, Savelkoul PHM, Roekaerts PMHJ, et al. Endotracheal aspirate and bronchoalveolar lavage fluid analysis: interchangeable diagnostic modalities in suspected ventilator-associated pneumonia? J Clin Microbiol. 2014;52(10):3597-604.

78. Textoris J, Loriod B, Benayoun L, Gourraud P-A, Puthier D, Albanèse J, et al. An evaluation of the role of gene expression in the prediction and diagnosis of ventilator-associated pneumonia. Anesthesiology. 2011;115(2):344-52

79. Vanspauwen MJ, Linssen CFM, Bruggeman CA, Jacobs JA, Drent M, Bergmans DCJJ, et al. Clara cell protein in bronchoalveolar lavage fluid: a predictor of ventilator-associated pneumonia? Crit Care. 2011;15(1):R14.

80. Vernikos P, Kampolis CF, Konstantopoulos K, Armaganidis A, Karakitsos $P$. The role of bronchoscopic findings and bronchoalveolar lavage fluid cytology in early diagnosis of ventilator-associated pneumonia. Respir Care. 2016;61(5):658-67.

81. Waltrick R, Possamai DS, de Aguiar FP, Dadam M, de Souza Filho VJ, Ramos $\mathrm{LR}$, et al. Comparison between a clinical diagnosis method and the surveillance technique of the Center for Disease Control and Prevention for identification of mechanical ventilator-associated pneumonia. Rev Bras Ter Intensiva. 2015;27(3):260-5. 
82. Yagmurdur $\mathrm{H}$, Tezcan $\mathrm{AH}$, Karakurt $\mathrm{O}$, Leblebici F. The efficiency of routine endotracheal aspirate cultures compared to bronchoalveolar lavage cultures in ventilator-associated pneumonia diagnosis. Niger I Clin Pract. 2016;19(1):46-51.

83. Zagli G, Cozzolino M, Terreni A, Biagioli T, Caldini AL, Peris A. Diagnosis of ventilator-associated pneumonia: a pilot, exploratory analysis of a new score based on procalcitonin and chest echography. Chest. 2014;146(6):1578-85.

84. Umemneku Chikere CM, Wilson K, Graziadio S, Vale L, Allen AJ. Diagnostic test evaluation methodology: a systematic review of methods employed to evaluate diagnostic tests in the absence of gold standard —an update. PLoS ONE. 2019;14(10):e0223832.

85. Lalwani S, Mathur P, Tak V, Janani S, Kumar SI, Bagla R, et al. Diagnosis of ventilator-associated pneumonia: comparison between ante-mortem and post-mortem cultures in trauma patients. Indian J Med Microbiol. 2014;32(3):294-300

86. Fernando SM, Tran A, Cheng W, Klompas M, Kyeremanteng K, Mehta S, et al. Diagnosis of ventilator-associated pneumonia in critically ill adult patients-a systematic review and meta-analysis. Intensive Care Med. 2020:46(6):1170-9.

87. Morris AC, Kefala K, Simpson AJ, Wilkinson TS, Everingham K, Kerslake D, et al. Evaluation of the effect of diagnostic methodology on the reported incidence of ventilator-associated pneumonia. Thorax. 2009;64(6):516-22.

88. Kamel T, Helms J, Janssen-Langenstein R, Kouatchet A, Guillon A, Bourenne J, et al. Benefit-to-risk balance of bronchoalveolar lavage in the critically ill. A prospective, multicenter cohort study. Intensive Care Med. 2020;46(3):463-74.

89. Browne E, Hellyer TP, Baudouin SV, Conway Morris A, Linnett V, McAuley $D F$, et al. A national survey of the diagnosis and management of suspected ventilator-associated pneumonia. BMJ Open Respir Res. 2014;1(1):e000066.
90. Butler KL, Sinclair KE, Henderson VJ, McKinney G, Mesidor DA, KatonBenitez I, et al. The chest radiograph in critically ill surgical patients is inaccurate in predicting ventilator-associated pneumonia. Am Surg. 1999;65(9):805-9 (discussion 809).

91. Wunderink RG, Woldenberg LS, Zeiss J, Day CM, Ciemins J, Lacher DA. The radiologic diagnosis of autopsy-proven ventilator-associated pneumonia. Chest. 1992;101(2):458-63.

92. Lefcoe MS, Fox GA, Leasa DJ, Sparrow RK, McCormack DG. Accuracy of portable chest radiography in the critical care setting. Chest. 1994;105(3):885-7.

93. Beards SC, Jackson A, Hunt L, Wood A, Frerk CM, Brear G, et al. Interobserver variation in the chest radiograph component of the lung injury score. Anaesthesia. 1995;50(11):928-32.

94. Rubenfeld GD, Caldwell E, Granton J, Hudson LD, Matthay MA. Interobserver variability in applying a radiographic definition for ARDS. Chest. 1999;116(5):1347-53.

95. Klompas M, Magill S, Robicsek A, Strymish JM, Kleinman K, Evans RS, et al. Objective surveillance definitions for ventilator-associated pneumonia. Crit Care Med. 2012;40(12):3154-61.

96. Moher D, Liberati A, Tatzlaff J, Altman DG, The PRISMA Group. Preferred reporting items for systematic reviews and meta-analyses: the PRISMA statement. PLos Med. 2009; 6(6):e1000097. https://doi.org/10.1371/journ al.pmed1000097

\section{Publisher's Note}

Springer Nature remains neutral with regard to jurisdictional claims in published maps and institutional affiliations.
Ready to submit your research? Choose BMC and benefit from:

- fast, convenient online submission

- thorough peer review by experienced researchers in your field

- rapid publication on acceptance

- support for research data, including large and complex data types

- gold Open Access which fosters wider collaboration and increased citations

- maximum visibility for your research: over 100M website views per year

At BMC, research is always in progress.

Learn more biomedcentral.com/submissions 